\title{
Spectrophotometric Determination of Eflornithine Hydrochloride using Vanillin as Derivative Chromogenic Reagent
}

\author{
Amit Kumar ${ }^{1 *}$, Vijender Singh ${ }^{2}$ and Praveen Kumar ${ }^{3}$ \\ ${ }^{1}$ Department of Chemistry, NKBR College of Pharmacy \& Research Centre, Meerut, Uttar Pradesh-245206, ${ }^{2}$ Department of \\ Chemistry, BBS Institute of Pharmaceutical \& Allied Sciences, Noida-201306, ${ }^{3}$ Department of Chemistry, MET-Faculty of \\ Pharmacy, Moradabad, Uttar Pradesh-244102, India
}

*For correspondence: Email: amit_analysis@yahoo.co.in; Tel: +919897144639; Fax: +91-121-2883334

\begin{abstract}
Purpose: To develop and validate a spectrophotometric method for the quantitative determination of eflornithine hydrochloride as a pure compound and in pharmaceutical formulations.

Methods: The method involved the reaction of the target compound with vanillin reagent at specific $\mathrm{pH}$ 5.6 to produce a green reddish color chromogen. The derivative chromogen exhibits absorption maxima at $578 \mathrm{~nm}$. At the $\mathrm{pH}$ of the reaction, there was no degradation. The developed method was validated as per International Conference of Harmonization (ICH) guidelines with respect to specificity, linearity, limit of detection, limit of quantification, accuracy, precision and robustness.

Results: Under the indicated conditions, the proposed method was linear over the concentration range of $5-25 \mu \mathrm{g} / \mathrm{ml}$ and the correlation coefficient $\left(r^{2}\right)$ was $>0.998(n=6)$ with a relative standard deviation (RSD) of $1.003 \%(n=6)$. Mean recovery of the target compound was $100.58 \%$ with a limit of quantification (LOQ) of $4.3 \mu \mathrm{g} / \mathrm{ml}$ and limit of detection (LOD) of $1.2 \mu \mathrm{g} / \mathrm{ml}$.

Conclusion: The results demonstrate the stability-indicating power of the proposed method which is precise, accurate, simple and economic. Thus, the method can be applied to the routine analysis of eflornithine hydrochloride in bulk and pharmaceutical formulations.
\end{abstract}

Keywords: Eflornithine hydrochloride, Vanillin, Spectrophotometric assay, Validation, ICH guidelines

\begin{abstract}
Tropical Journal of Pharmaceutical Research is indexed by Science Citation Index (SciSearch), Scopus, International Pharmaceutical Abstract, Chemical Abstracts, Embase, Index Copernicus, EBSCO, African Index Medicus, JournalSeek, Journal Citation Reports/Science Edition, Directory of Open Access Journals (DOAJ), African Journal Online, Bioline International, Open-J-Gate and Pharmacy Abstracts
\end{abstract}

\section{INTRODUCTION}

Eflornithine hydrochloride (difluoromethylornithine, DFMO) is a selective, irreversible inhibitor of ornithine decarboxylase enzyme, one of the key enzymes in the polyamine biosynthetic pathway [1]. Eflornithine hydrochloride (DFMO) has the chemical name (2-fluoromethyl- -ornithine).

DFMO is an antiprotozoal agent which is used for meningoencephalic stage of trypanosomiasis. It is caused by Trypanosoma brucei gambienze, African trypanosomiasis [1,2]. DFMO is effective in the treatment of facial hirsutism [3] as well as in African trypanosomiasis, also known as sleeping sickness [2].

The methods available for the determination of DFMO include high pressure liquid chromatography techniques [3-5]. The high pressure liquid chromatography methods available for the determination of eflornithine involve either pre- or post-column derivatization 
with UV or fluorescence detection $[6,7]$ and LC carried out by evaporative light scattering detection [8]. Few analytical developed methods have been proposed for the determination of DFMO $[9,10]$.

The aim of this work was to develop a sensitive and simple spectrophotometric method for the quantification of DFMO using a specific derivative chromogenic reagent (vanillin) for the analysis of the target compound in pharmaceutical preparations without the requirement of further separation.

The developed techniques were validated for parameters including linearity, accuracy, precision, specificity and selectively, detection and quantification limits.

\section{EXPERIMENTAL}

\section{Materials and reagents}

All chemicals and reagents used were of analytical grade purity, taken in an accurate amount and was not further standardized. Eflornithine hydrochloride is marketed under the trade name Ornidyl. Each sample vial (SVP) is containing $200 \mathrm{mg} / \mathrm{ml}$. The pure drug (DFMO) was a gift from Wintac Limited, Bangalore, India. Reagents used included vanillin, potassium hydrogen phthalate, sodium hydroxide, hydrochloric acid potassium dihydrogen phosphate were supplied from Merk Germany. Anhydrous glacial acetic acid (GAA) was purchased from Rankam group Ltd, Hong Kong. Double-distilled water was used through this study.

\section{Preparation of solutions}

Universal buffer solution of different $\mathrm{pH}$ values ranging from 2 to 6 were prepared by adjusting $100 \mathrm{ml}$ solution of the acid mixture to the desired ph value using $0.1 \mathrm{~N} \mathrm{NaOH}$ solutions. Acid phthalate buffer and neutralised phthalate buffer solutions were prepared using recommended method by Indian Pharmacopoeia [11].

Potassium hydrogen phthalate and potassium dihydrogen phosphate (each $0.2 \mathrm{M}$ ) solutions were prepared by dissolving the accurately weighed (40.86 and $27.218 \mathrm{~g}$ ) of potassium hydrogen phthalate in double distilled water and was made up to the mark in a $1000 \mathrm{ml}$ volumetric flask respectively.

Vanillin solution ( $1 \% \mathrm{w} / \mathrm{v})$ was prepared by dissolving the accurately weighed $1 \mathrm{~g}$ of vanillin in double distilled water and was made up to the mark in a $100 \mathrm{ml}$ volumetric flask.

\section{Apparatus}

Spectrophotometric measurements were carried out on a UV-1700 Shimadzu double beam spectrophotometer (Japan) with a fixed slit width of $2 \mathrm{~nm}$ using a pair of $1 \mathrm{~cm}$ matched quartz cells. All $\mathrm{pH}$ measurements were made with Digisun D1-707 digital $\mathrm{pH}$ meter.

\section{Preparation of stock solutions of DFMO}

Eflornithine hydrochloride (100 mg) was dissolved in anhydrous glacial acetic acid (GAA) into $100 \mathrm{ml}$ volumetric flask and was made up to the mark in a $100 \mathrm{ml}$ volumetric flask. Now pipette $50 \mathrm{ml}$ of this solution and diluted up to $100 \mathrm{ml}$ with (GAA) to get $500 \mu \mathrm{g} / \mathrm{ml}$.

This solution was prepared daily. Working standard solutions were prepared immediately before use by a suitable dilution of the corresponding stock solution to appropriate concentration levels by using anhydrous GAA as the diluent.

\section{Preparation of sample solution}

Twenty vials of Ornidyl $200 \mathrm{mg} / \mathrm{ml}$ were used. The sample vial (SVP) containing $200 \mathrm{mg} \mathrm{ml}^{-1}$. Pipetted out $1 \mathrm{ml}$ and diluted to $100 \mathrm{ml}$ with anhydrous GAA. Now pipette $50 \mathrm{ml}$ of this solution and diluted up to $100 \mathrm{ml}$ with GAA to get $500 \mu \mathrm{g} / \mathrm{ml}$.

\section{Determination of absorption maxima of eflornithine (DFMO)}

An aliquot $(0.5 \mathrm{ml})$ of standard eflornithine hydrochloride (DFMO) solution of $500 \mu \mathrm{g} / \mathrm{ml}$ was pipetted into a $25 \mathrm{ml}$ volumetric flask. To this 10 $\mathrm{ml}$ of Phthalate buffer (pH 5.6) and $3.5 \mathrm{ml}$ of $1 \%$ $\mathrm{w} / \mathrm{v}$ reagent solution of vanillin were added and heated on a water bath for $1 \mathrm{~h}$ at $90^{\circ} \mathrm{C}$. After one hour, solution was cooled to room temperature. The final volume was made up to $25 \mathrm{ml}$ with double-distilled water and resultants green reddish color solution was then scanned 400-800 $\mathrm{nm}$.

\section{Determination of eflornithine (DFMO) using vanillin}

The linearity of the method was demonstrated over the concentration range of $5-25 \mu \mathrm{g} / \mathrm{ml}$ for DFMO. Aliquots of $0.25 \mathrm{ml}, 0.5 \mathrm{ml}, 0.75 \mathrm{ml}, 1 \mathrm{ml}$, $1.25 \mathrm{ml} 3.5 \mathrm{ml}^{\circ} 500 \mathrm{\mu g} \mathrm{ml}^{-1}$ solution of standard eflornithine (DFMO) was pipetted into five $25 \mathrm{ml}$ 
volumetric flasks respectively. $10 \mathrm{ml}$ of phthalate buffer solution ( $\mathrm{pH} \mathrm{5.6)}$ and $3.5 \mathrm{ml}$ of $1 \% \mathrm{w} / \mathrm{v}$ reagent solution of vanillin were added and heated on a water bath for $1 \mathrm{~h}$ at $90{ }^{\circ} \mathrm{C}$. The volumetric flasks were cooled to room temperature and volume was made up to $25 \mathrm{ml}$ with double-distilled water. The absorbance of solutions was measured at $578 \mathrm{~nm}$ against blank.

\section{Procedure for the parenteral formulations}

Twenty vials of Ornidyl $200 \mathrm{mg} / \mathrm{ml}$ were used. The sample vial (SVP) containing $200 \mathrm{mg} / \mathrm{ml}$ was pipetted out and diluted to $100 \mathrm{ml}$ with anhydrous glacial acetic acid (GAA). Now further dilutions were done with GAA to get the final concentration of $500 \mu \mathrm{g} / \mathrm{ml}$. The procedure mentioned above was followed where different concentrations of Ornidyl in the range of 5-25 $\mu \mathrm{g} / \mathrm{ml}$ were added respectively. The drug concentration was calculated from the standard calibration graph prepared under identical conditions.

\section{Effect of $\mathrm{pH}$ on DFMO-vanillin derivative chromogenic reaction}

An aliquot $(1 \mathrm{ml})$ of eflornithine hydrochloride solution of $500 \mu \mathrm{g} / \mathrm{ml}$ was pipetted into each of eight $25 \mathrm{ml}$ volumetric flasks. To this $10 \mathrm{ml}$ of phthalate buffer solution of various $\mathrm{pH} 2.6,3,3.4$, 4, 4.6, 5, 5.6 and 6 was added to each $25 \mathrm{ml}$ volumetric flasks, respectively. This was followed by $3.5 \mathrm{ml}$ of $1 \% \mathrm{w} / \mathrm{v}$ solution of vanillin to all volumetric flasks and heated on a water bath at $90{ }^{\circ} \mathrm{C}$ for $1 \mathrm{~h}$ and cooled to room temperature .The final volume of each volumetric flask was made up to $25 \mathrm{ml}$ with double-distilled water. The absorbance was measured at $578 \mathrm{~nm}$ against reagent blank.

\section{Effect of volume of buffer solution on DFMO- VANILLIN derivative chromogenic reaction}

An aliquot of $1 \mathrm{ml}$ eflornithine hydrochloride (DFMO) solution of $500 \mu \mathrm{g} / \mathrm{ml}$ was pipetted into each of five $25 \mathrm{ml}$ volumetric flasks respectively. To this various volumes of phthalate buffer solutions of $\mathrm{pH} 5.6, \mathrm{viz}, 2.5,5,7.5,10$ and 12.5 $\mathrm{ml}$ were added to each series of volumetric flasks respectively. This was followed by addition of 3.5 $\mathrm{ml}$ of $1 \% \mathrm{w} / \mathrm{v}$ solution of vanillin to all volumetric flasks and heated on a water bath for $1 \mathrm{~h}$ at 90 ${ }^{\circ} \mathrm{C}$ and cooled to room temperature. The final volume was made up to $25 \mathrm{ml}$ with doubledistilled water. The absorbance was measured at $578 \mathrm{~nm}$ against reagent blank.

\section{Effect of the vanillin concentration on the vanillin-DFMO reaction}

The optimum vanillin-DFMO ratio for the DFMOVanillin reaction was determined by adding varying volumes of vanillin solutions to a known constant concentration of DFMO. An aliquot of 1 $\mathrm{ml}$ eflornithine hydrochloride (DFMO) solution of $500 \mu \mathrm{g} / \mathrm{ml}$ was pipetted into each of eight $25 \mathrm{ml}$ volumetric flasks respectively. $10 \mathrm{ml}$ of phthalate buffer solution ( $\mathrm{pH} 5.6)$ was added to each volumetric flask respectively and followed by 0.5 , $1,1.5,2,3 \mathrm{ml}, 3.5,4$ and $5 \mathrm{ml}$ of $1 \% \mathrm{w} / \mathrm{v}$ reagent solution of vanillin to each volumetric flask respectively. The volumetric flasks were heated on a water bath for $1 \mathrm{~h}$ at $90{ }^{\circ} \mathrm{C}$ and cooled to room temperature. The final volume was made up to $25 \mathrm{ml}$ with double distilled water. The absorbance was measured at $\lambda_{\max } 578 \mathrm{~nm}$ against reagent blank.

\section{Effect of heating time on the DFMO-vanillin reaction}

An aliquot of $2 \mathrm{ml}$ and $3 \mathrm{ml}$ of $500 \mu \mathrm{g} / \mathrm{ml}$ of eflornithine hydrochloride solution was pipetted into each of six $25 \mathrm{ml}$ volumetric flasks respectively. $10 \mathrm{ml}$ phthalate buffer $(\mathrm{pH} 5.6)$ and $3.5 \mathrm{ml}$ of $1 \% \mathrm{w} / \mathrm{v}$ solution of reagent vanillin were added to each of volumetric flasks respectively and heated on a water bath at different times i.e., $00 \mathrm{~min}, 15 \mathrm{~min}, 30 \mathrm{~min}, 45$ min, $60 \mathrm{~min}$ and $75 \mathrm{~min}$ at $90^{\circ} \mathrm{C}$. The volumetric flasks were cooled to room temperature and the volume was made up to $25 \mathrm{ml}$ with double distilled water. The absorbance of each solution was measured at $578 \mathrm{~nm}$ against blank.

\section{Statistical analysis}

The data obtained are presented as mean \pm standard deviation (SD). Statistical analysis was performed using one-way ANOVA with the aid of Microsoft Excel 2003 software. Differences between formulations were considered significant at $p \leq 0.05$.

\section{RESULTS}

\section{Reliability}

The results of reliability studies showed that the proposed derivative chromogenic spectrophotometric method is highly reproducible during one run and between different runs. The low values of $\%$ RSD for reliability studies (Table 1 ) indicate that there was no statistically significant difference $(p \leq 0.05)$ between the two different 
UV spectrophotometer instruments used in similar settings.

\section{Validation results}

The proposed method was validated according to $\mathrm{ICH}$ guidelines (12) in terms of linearity, accuracy, precision LOD and LOQ. The validation results indicate good linearity parameters of the proposed method (Table 2).

\section{Accuracy}

The accuracy of the proposed method was established by measuring the content of eflornithine hydrochloride in pure form at different concentration levels. The percentage recovery of eflornithine hydrochlode was found to be in the range of 99.17 to $100.58 \%$ (Table 3 ).

\section{Precision}

The precision of the proposed method was determined by measuring the content of eflornithine hydrochloride in pure form at different concentration levels. Inter- and intra-day precision of the proposed method is performed by carrying out three replicate experiments at each concentration level within four days and shown in Table 4.

Table 1: Results of reliability studies

\begin{tabular}{lccc}
\hline UV spectrophotometer & $\begin{array}{c}\text { Amount taken } \\
(\boldsymbol{\mu} \mathbf{g} / \mathbf{m l})\end{array}$ & Amount found $(\boldsymbol{\mu g} / \mathbf{m l})$ & \% RSD* \\
\hline Equipment 1 & 15 & $14.98 \pm 0.01$ & 0.082 \\
Equipment 2 & 15 & $14.96 \pm 0.02$ & 0.173 \\
\hline${ }^{*} R S D=$ relative standard deviation & & &
\end{tabular}

Table 2: Linearity parameters of the proposed method

\begin{tabular}{lc}
\hline Linearity parameter & DFMO \\
\hline$\lambda_{\max (\mathrm{nm})}$ & 578 \\
Drug's linearity ranges $(\mu \mathrm{g} / \mathrm{ml})$ & $5-25$ \\
Molar extinction coefficient $\left(\mathrm{Lmole}^{-1} \mathrm{~cm}^{-1}\right)$ & $1.35 \times 10^{2}$ \\
Sandall's sensitivity $\left(\mu \mathrm{gcm}^{-2}\right)$ & 0.783 \\
Intercept & 0.07 \\
Slope & 0.0073 \\
Correlation coefficient $\left(\mathrm{r}^{2}\right)$ & 0.9987 \\
Percentage recovery $(\%)$ & $99.17-100.58$ \\
SD & $0.62-0.64$ \\
RSD $(\%)$ & $0.997-1.003$ \\
LOD $(\mu \mathrm{g} / \mathrm{ml})$ & 1.2 \\
LOQ $(\mu \mathrm{g} / \mathrm{ml})$ & 4.3 \\
\hline
\end{tabular}

Table 3: Accuracy of the proposed method

\begin{tabular}{lcccc}
\hline Analyte & $\begin{array}{c}\text { Amount } \\
\text { taken } \\
(\boldsymbol{\mu} \mathrm{g} / \mathrm{ml})\end{array}$ & $\begin{array}{c}\text { Amount } \\
\text { added } \\
(\boldsymbol{\mu} \mathrm{g} / \mathrm{ml})\end{array}$ & $\begin{array}{c}\text { Amount } \\
\text { found } \\
(\boldsymbol{\mu g} / \mathrm{ml})\end{array}$ & ${\text { Recovery } \pm R S D(\%)^{*}}$ \\
\hline DFMO & 10 & 5 & 14.87 & $99.17 \pm 0.091$ \\
& 10 & 10 & 20.02 & $100.11 \pm 0.85$ \\
& 10 & 15 & 25.14 & $100.58 \pm 0.31$ \\
\hline
\end{tabular}

${ }^{*} n=6$

Table 4: Intra- and inter-day precision

\begin{tabular}{lllll}
\hline DFMO & & \multicolumn{3}{c}{$\%$ recovery* } \\
\hline $\begin{array}{l}\text { Conc. } \\
(\boldsymbol{\mu g} / \mathrm{ml})\end{array}$ & $\begin{array}{l}\text { Intra-day } \\
(\% R S D)\end{array}$ & $\begin{array}{l}\text { Inter-day } \\
(\% R S D)\end{array}$ & Intra-day & Inter-day \\
\hline 5 & 1.0094 & 1.0222 & 100.2 & 99.60 \\
15 & 0.9925 & 0.9765 & 99.56 & 98.89 \\
25 & 0.9896 & 1.0091 & 98.75 & 101.23 \\
\hline
\end{tabular}

${ }^{*}$ Average of six readings 


\section{Recovery experiment of commercial formulation}

Applicability of the method was tested by analyzing the commercially available vials formulation containing DFMO (ornidyl, label claim, $200 \mathrm{mg} / \mathrm{ml} / \mathrm{vial}$ ). The assay of commercial formulation (ornidyl) was done with $5 \mu \mathrm{g} / \mathrm{ml}$. the concentration was found $5.05 \mu \mathrm{g} / \mathrm{ml}$. Recovery from formulation was $100.5 \pm 0.98$. Data were very close to each other as well as to the label strength of the reference commercial pharmaceutical formulation, which shows that the method can be applicable to the determination of DFMO in formulations.

\section{DISCUSSION}

Many researchers have studied eflornithine hydrochloride separately in dosages forms [810]. The good regression coefficient indicates that Beer's was obeyed. The experimental factors affecting the development and stability of the colored chromogens produced were carefully studied. The optimum $\mathrm{pH}$ of potassium hydrogen phthalate buffer required to produce stable chromogen (green reddish color chromogen) having maximum absorbance was found to be 5.6. The colored chromogens were stable for at least $1 \mathrm{~h}$ which permits the convenient application of the proposed method. At pH 6 the green reddish color chromogen disappears and the solution changes to brownish-black indicating the degradation of the chromogen, and the degradant exhibit an absorbance of 0.1023 at $578 \mathrm{~nm}$.

Different experimental conditions, especially $\mathrm{pH}$ and vanillin concentration, were carefully selected as they could greatly affect the quantification of the target compound. As reported, the reactivity of compounds possessing a primary amino group is $\mathrm{pH}$ specific. Attempts were made to improve $\mathrm{pH}$ control in the target reaction. It has been carried out by several assays of solutions containing 5,15 and 20 $\mu \mathrm{g} / \mathrm{ml}$ of DFMO and $10 \mathrm{ml}$ of different buffer solutions that covered a wide $\mathrm{pH}$ range. As a result of this experience, it is necessary to maintain a $\mathrm{pH}$ of 5.6 as optimum to obtain the derivative chromogen. Several buffers of different compositions could be used but the best results were obtained with an acid phthalate buffer solution of $0.2 \mathrm{M}$ of $\mathrm{pH}$ 5.6. The volume of buffer necessary to obtain the highest and most stable absorbance was determined and established as $10 \mathrm{ml}$.

The optimum volume of $3.5 \mathrm{ml}$ of $1 \% \mathrm{w} / \mathrm{v}$ of vanillin reagent was required to produce a stable chromogen with a maximum absorbance at 578 $\mathrm{nm}$. Efornithine hydrochloride (DFMO) derivative chromogen showed maximum absorbance after heating for $60 \mathrm{~min}$ at $90{ }^{\circ} \mathrm{C}$. The reaction between DFMO and vanillin (Figure 1) was spontaneous and produced a coloured complex which was quite stable for over one hour, giving enough time for the analysis. Recovery experiment showed high quantitative recoveries with low standard deviation by the proposed assay method.

The effect of vanillin concentration on the derivative chromogen formation was observed by measuring the absorbance at different vanillinDFMO concentration ratios, while all other experimental conditions were kept constant at the optimum values. In subsequent work, vanillinDFMO ratio of 600:1 was employed as the minimum for the determination of DFMO throughout the rest of the experimental work. The order of mixing of the analyte, buffer, NQS and water to obtain the derivative chromogen was examined. No appreciative changes were observed, hence the choice of analyte, buffer, vanillin for the present study.

In order to obtain optimum derivative chromogen with the highest and most stable absorbance, the effect of the reaction time and heating temperature on the absorbance of the reaction product was studied. The reaction was carried out at different temperatures using thermostated water. Maximum and constant absorbance was obtained at $90^{\circ} \mathrm{C}$ after $60 \mathrm{~min}$.

\section{Reaction of the proposed method}

Vanillin could react with the amino group of primary amino derivative. Alpha amino group of DFMO displays nucleophilicity due to the fact that its lone pairs of electrons of nitrogen can attack the electron deficient center. Hence DFMO can react with vanillin in a condensation reaction. Vanillin to form Schiff's base, the possible reaction equation is shown in Fig. 1.

\section{CONCLUSION}

The data obtained show that the proposed method is simple, accurate and sensitive with good precision and accuracy. Also, the reagent utilized in the proposed method is low-cost, readily available and the procedures do not involve any or tedious sample preparation. The short analysis time and low cost reagents used are also benefits of this method. Thus, the method can be applied for the determination of eflornithine hydrochloride in pure form and in pharmaceutical preparations. 
<smiles>NCCCC(N)(C(=O)O)C(F)F</smiles>

Eflornithine hydrochloride

$$
\begin{aligned}
& \text { Buffer volume } 10 \mathrm{ml}(\mathrm{pH} \\
& 5.6) ; \text { temerature } 90^{\circ} \mathrm{C} ; \\
& \text { time } 60(\text { min); reagent } \\
& \text { volume } 3.5 \mathrm{ml}(1 \% \mathrm{w} / \mathrm{v}) .
\end{aligned}
$$<smiles>COc1cc(C=O)ccc1O</smiles>

Vanillin<smiles>COc1cc(C=NC(CCCN)(C(=O)O)C(F)F)ccc1O</smiles>

\section{DFMO-VANILLIN DERIVATIVE CHROMOGEN}

Figure 1: Reaction of the proposed method

\section{ACKNOWLEDGEMENT}

This work forms a part of the PhD thesis of $\mathrm{Mr}$ Amit Kumar of School of Pharmaceutical Sciences, IFTM University, Moradabad 244102, India. The authors acknowledge the kind gift of eflornithine hydrochloride from Wintac Limited, Bangalore, India.

\section{REFERENCES}

1. Merali S, Clarkson $A B$ (Jr). Polyamine content of Pneumocystis carinii and response to the ornithine decarboxylase inhibitor DL-alphadifluoromethylornithine". Antimicrob Agents Chemother 1996; 40: 973-978.

2. Pepin J, Guern $C$, Milord $F$, Schechter PJ. "Difluoromethylornithine for arseno-resistant trypanosoma brucei gambiense sleeping sickness". Lancet 1987; 330: 1431-1433.

3. Cohen JL, Ko RJ, Lo AT, Shields MD, Gilman TM. "Highpressure liquid chromatographic analysis of DFMO in serum". J Pharm Sci. 1989; 78(2): 114-116.

4. Huebert ND, Schwartz JJ, Haegele KD. "Analysis of 2difluoromethyl-DL-ornithine in human plasma, cerebrospinal fluid and urine by cation-exchange high-performance liquid chromatography". J Chromatogr A. 1997; 21; 762(1-2): 293-298.

5. Saravanan $C$, Kumudhavalli MV, Kumar M, Jayakar B. A new validated RP-HPLC method for estimation of DFMO hydrochloride in tablet dosage form. J Pharm Res.2009; 2: 1730-1731.

6. Kilkenny ML, Slavik M, Christopher MR, Stobaugh JF. "Plasma analysis of alpha-difluoromethylornithine using pre-column derivatization with naphthalene-2,3dicarboxaldehyde/CN and multidimensional chromatography". J. Pharm. Biomed. Anal. 1998; 17: 1205-1213.

7. Jansson-Löfmark $R$, Römsing $S$, Albers E, Ashton $M$. "Determination of eflornithine enantiomers in plasma by precolumn derivatization with o-phthalaldehyde-Nacetyl-L-cysteine and liquid chromatography with UV detection”. Biomed. Chromatogr. 2010; 24: 768-773.

8. Malm M, Bergqvist $Y$. "Determination of DFMO enantiomers in plasma, by solid-phase extraction and liquid chromatography with evaporative lightscattering detection". J. Chromatogr. B: Analyt. Technol. Biomed. Life Sci. 2007; 846: 98-104.

9. Kumar A, Venkatesh Prasad SP, Mohan S, Kumar P. Spectrophotometric determination of eflornithine 
hydrochloride as active pharmaceutical ingredient using sodium 1,2-naphthoquinone-4-sulfonate as the derivative chromogenic reagent". Trade Sci. Inc. 2008; 7(2): 225.

10. Kumar A, Venkatesh Prasad SP, Mohan S, Singh AK. Estimation of eflornithine hydrochloride by uv Spectroscopy". Trade Sci. Inc. 2009; 8: 117-124.
11. The Controller of publication. Indian Pharmacopoeia, 2007; Vol 2; pp 144-145.

12. ICH Harmonised Tripartite Guideline 2005. International Conference on Hormonisation of Technical Requirements for Registration of Pharmaceuticals for Human Use, Validation of Analytical Procedures: Text and Methodology Q2 (R1), Complementary Guideline on Methodology, London, pp 11-12. 